\title{
The Probable Effects of the Modernization of the Customs Union Upon the International Road Transportation Sector: Izmir Region Example
}

\author{
Ulviyye Aydin ${ }^{1 *}$, Ahmet Ucar², Rasim Akpinar ${ }^{3}$ \\ 1,2,3 Manisa Celal Bayar University, Turkey \\ *Corresponding author: ulaydin91@ hotmail.com
}

\begin{abstract}
This study aims to detect the probable effects of the modernization of the European Union (EU) - Turkey Customs Union upon the international road transportation sector. Izmir region has been selected as a research area. Izmir is located in the Aegean region, which is the third biggest city and second biggest port of Turkey. With its developed industry due to the region's raw material resources, qualified labor force, and wide range of transportation opportunities, Izmir is one of the important trade centers, ranking second after the Marmara Region in terms of industry. Closeness to the landlocked centers with high processing capacities such as Manisa, Denizli, Aydin, Mugla, Bursa, Usak, Kutahya, and the presence of around 1,700 companies with international capital makes Izmir more critical for the logistics sector. Thus, it is considered an acceptable sample area for the research. A semistructured interview technique has been used in the investigation. According to the results of interviews with 19 international road transporters in Izmir, the modernization of the Customs Union will increase Turkey's competitiveness of trading in goods and services with the EU countries. Removing the obstacles like visa problems, limitations on the free movement of drivers and transportation services, transit tolls that the Turkish road transport companies face in the EU member states, the modernization of the Customs Union will benefit both Turkish road transporters and exporters, as well as increase trade volume between the sides.
\end{abstract}

Keywords: Customs Union, European Union, international road transportation sector, Izmir, modernization, Turkey.

\section{Introduction}

"Globalization" is the most used concept of recent years. While it shortly means economic, social and political changes in the world and growing interdependence between countries, in economic terms, globalization expresses increasingly becoming dependant of different states' markets and productions to each other 
through mutual movements of goods, services, capital and labor and technology transfers (Yilmaz, 2013: p.209). Some economists explain the present world economic order on the base of Adam Smith's arguments. According to this, the whole world economy is a free market, where an optimal distribution of production factors between nations and free movement of factors will maximize the world production and consumption. Thus, universalizing the international division of labor, increasing and diversified world total production of goods and services can be attained. However, the second group of scholars argues that global integration can be gradually achieved by regional economic integration (Yilmaz, 2013: p.209). Generally, five stages of integration are envisaged (Table 1).

\section{Table 1}

Stages of Regional Economic Integration
Stages
Scope of stages

Free Trade Area

Tariffs (a tax imposed on imported goods) between member countries are significantly reduced, some abolished altogether. Each member country keeps its own tariffs in regard to third countries.

Customs Union $\quad$ Free Trade Area + common foreign trade policy in regard to third countries.

Common Market Customs Union + free movement of persons, services and capital.

Monetary Union Common Market + common currency.

Economic Union Monetary Union + common economic policies.

Source: Adopted from Gocmen, 2016: p.386.

It is not expected to start a mentioned five-phased integration process with the establishment of the Free Trade Area. The economic integration movements started from the second stage - Customs Union - can also follow the paths above step by step, but their main goal must focus on the final stage - Economic Union (Dedeoglu, 2015: p.223).

Within this context, with Turkey's application for membership, a new process has started based on a legal structure that was not tested in the EU's acquis before. Until 
then, a candidate state was enrolled as a full member of the European Community (EC) within the enlargement process of the EC, and the Customs Union started after - within 5-7 years. However, Turkey - the EU Customs Union has started without the full membership of Turkey. Status granted to Turkey has caused its inability to benefit from the EU's structural funds (Karluk 2005) during the past years. While the start of membership negotiations can be accepted as an achievement for Turkey, however, taking the time elapsed since the application date into account, this should be considered a significant delay (Gursel \& Dedeoglu, 2010: p.177). The relationship between the two sides continues through the Customs Union, which cannot respond to today's conditions. While discussions for updating the Customs Union started in 2001, Turkey withdrew from the debates because the draft text did not meet the demands of the Turkish side. In 2002-2004 the sides discussed the services and public procurements within the Customs Union, but a decision to start membership negotiations interrupted these discussions. Until now, neither the Customs Union has been updated, nor has there been any conclusion regarding membership.

This paper is based on the findings of the project that aimed to evaluate the probable effects of the modernization of the EU-Turkey Customs Union upon the international road transportation sector. The project's proposed method was a semi-structured interview. The paper is structured as follows: Section 1 - the losses of Turkey due to the non-modernization of the Customs Union; Section 2 - used methodology; Section 3 - the study group of the project; Sections 4, 5, and 6 - data collection and data analysis; Section 7 - interpretation of the findings. The last section provides concluding remarks.

\section{Background of Study}

The Customs Union between the EU and Turkey is more than a known economic integration model. It is an essential step of Turkey's relations with the EU towards integration goals with the Union. Ankara Agreement of 1963 established the EUTurkey partnership relations and outlined the framework of the Customs Union. Article 28 of the mentioned agreement defined Turkey's membership as an ultimate goal of the partnership with the Union. The details of the Customs Union were specified in the Additional Protocol, which entered into force in 1973. The Ankara Agreement envisaged a progressive model of integration of Turkey, namely the establishment of a Customs Union that composed of preparatory, the transition and the completion phases. By the completion of Turkey's responsibilities, the Customs Union was completed and became operational from January 1, 1996, as a result of the Decision No: 1/95 of Turkey-EC Association Council. 
The mentioned Decision briefly covered the following issues:

- Free movement of goods: abolition of customs duties and quantity restrictions and compliance with the EU Customs Code;

- Common Trade Policy: compliance with the Common Customs Tariff, preferential trade agreements, autonomous regimes;

- Remove technical barriers to trade: harmonization of technical legislation;

- Legal regulations: intellectual and industrial property rights, competition rules, public procurement;

- Institutional cooperation: the establishment of partnership institutions.

Turkey-EU Customs Union had been prepared within the perspective of full membership. However, it has been in force more than the foreseen time (Iktisadi Kalkinma Vakfi (IKV), 2019). As a result, the Customs Union can not meet the demands of contemporary trading conditions. Moreover, during the last years, the EU has been established more comprehensive commercial relations with the third countries through the Free Trade Area. These new generation trade agreements cover a wide range of partnership areas such as agriculture, services, investments, and public procurement. The EU represents more than $40 \%$ of trade in Turkey, and it is the first trade partner of Turkey. So, there are two priorities for the modernization of the Customs Union. Those are to harmonize the EU-Turkey Customs Union with the developing and changing world trade conditions and Turkey's taking an active role in the decision-making of free movement processes. Only a modernized and deepened Customs Union can eliminate the disbalance in Turkey-EU commercial relations. In recent years Turkey has raised the issue of the modernization of the Customs Union with the EU. Within this context, technical negotiations have been conducted with the European Commission. After the completion in May 2015, the authorities of both sides stated that negotiations for the modernization of Turkey-EU Customs Union were going to begin.

Prior to these developments, the report on "Evaluation of the EU-Turkey Customs Union" was published by the World Bank upon the request of the European Commission in March 2014, where it has been suggested that the Customs Union should include agriculture, services, and public procurement also. Similarly, at the end of the 2016 European Commission has published an impact assessment on the modernization of the Turkey-EU Customs Union (IKV, 2019).

Some statistics will be useful for a better understanding of the economic losses of Turkey because of the Customs Union. For example, the EU has been Turkey's first foreign trade partner with 165 billion USD of trade in 2018 (TC Ticaret Bakanligi, 2019). Within this context, $1.033,504$ international road transportations have been 
completed in total. While Turkish transport companies have carried 409,133 of total 611,453 export transportations to the EU countries, 297,912 of total 422,051 import transportations to Turkey have been realized by Turkish companies (Uluslararasi Nakliyeciler Dernegi (UND), 2018). Only visas' annual cost for the Turkish international road transportation sector was about 7 million Euro, resulting in loss of labor and time. For Turkish drivers who spend one month of the year unemployed due to limited visa periods, 20 different documents are required for visa applications (UND, 2018). Due to the geographical features and proximity, international road transportation is the most used transport mode in trade between the European countries and Turkey. It is one of the sectors that intensively doing business in the EU member states.

Considering that the EU - Turkey Customs Union is insufficient to meet the needs of today's global trade, as a service provider, Turkey's international road transport sector is one of the areas that confront several problems within the EU borders. Therefore, this research aims to investigate the probable effects of the modernization of the Customs Union on Turkey's international road transportation sector.

\section{Methodology}

In order to predict the probable effects of modernization of the Customs Union upon the international road transport sector in the Izmir region, a semi-structured interview has been used as a qualitative research method. As it is known, a semi-structured interview is often preferred by researchers due to their certain level of standard and flexibility. While a semi-structured interview eliminates the limitations in tests and surveys based on writing and filling, it helps to obtain in-depth information on a particular subject (Yildirim \& Simsek, 2003). A semi-structured interview is neither as rigid as a fully structured interview nor as flexible as an unstructured interview, it is between these two. Because it provides researchers such an opportunity, a semistructured interview technique has been used in this study.

\section{Study Group}

The study group of this study consists of the members of the International Transporters Association (UND) located in the Izmir region. A two-step path was followed in the selection of the road transporter companies in the study group. The fundamental conception of the criterion sampling method is to study all situations that meet a predetermined set of criteria. The researcher may establish the criteria mentioned herein. However, convenience sampling speeds up the research and 
increases its practicality (Yildirim \& Simsek, 2006). Because of the difficulty of reaching all road transporter companies in Izmir and meeting with all of them, UND membership, location in Izmir, providing international road transportation service and transportation of the commercial goods to/from the EU countries have been determined as the main criteria of sample selection. Nineteen road transporters were determined among the UND members using criterion sampling and convenience sampling methods. All 19 transporters are located in Izmir that has been accessed easily. All of them transport commercial goods to/from the member states of the EU by road within the Customs Union. The selected international road transportation companies carry the import-export goods at least three EU member states.

\section{Data Collection Tool}

As a data collection tool, the semi-structured interview form has been used in the research. In the preparation of interview questions developed by the researchers, special attention has been paid to the principles, such as an easy understanding of the questions, not being multidimensional, not directing the responder. The interview form was presented to the sector experts in order to check its relevance, its clarity, and its applicability. An interview form has been revised according to the recommendations of the experts. Elaboratively constructed form consists of four parts and 11 questions. The first section consists of five questions that aim to determine the company profile. The second section includes three questions focusing on the company's service trade. The aim of this part is to determine the countries to/from where the company transports goods, both the EU and non-EU countries. There is one question in the third part with four options aiming to detect the problems that the Turkish international road transportation companies face in the EU member states. The final part of the form with two questions purpose to take the companies' opinions about the modernization of the Customs Union with the EU and, in case of its modernization, probable effects of it upon the international road transport companies.

Two researchers have participated in the interviews. While one of them has managed the interview, the second one has observed the process, has asked additional questions if necessary, and has asked for explanations. Thus, it was tried to prevent possible data loss and to ensure compliance of the data with the research questions.

\section{Data Collection}

The data of the study has been collected for one month. Nineteen company officials were interviewed separately according to the pre-arranged appointments. For the 
interview, locations and environments have been chosen by the participants in order to make the participants express themselves comfortably. The interview questions have been asked to each participant with the same words and intonations that evoke the same meaning. A voice recorder and note-taking techniques have been used together during the interviews. Later on, the records have been analyzed. Thirty-five pages of data have been obtained from the analysis of the interviews. First of all, the data has been transcribed, and the accuracy of the transcripts has been ensured. Then, according to the identified themes, data processing, and findings with direct quotations have been interpreted.

\section{Data Analysis}

The data obtained from the interview forms were analyzed using descriptive analysis in order to present the findings in an edited and interpreted manner. In the determination of the themes, the category creation method was used as the qualitative analysis method. Each participant was given a code as T1 (Transporter 1), T2 (Transporter 2) for analyzing the data and discussing the views of the participants within the framework of ethical rules. All interviews were recorded in the evaluation system according to the code numbers. After the registration, the data were evaluated under categories according to common or similar characteristics.

\section{Findings}

\section{Transporters' opinions on the EU countries where they face problems:}

The participants were asked the question of "In which EU country does your company confront a problem?". Only one participant (T15) answered that their company faces problems in all the EU countries (f:1). The other 18 participants answered that they mainly confront problems in Bulgaria, Romania, Hungary, Austria, Italy, and Slovenia (f:3).

Some answer examples for the question in which EU countries the Turkish transport companies confront problems:

a) "In Hungary and Romania, a repressive control system is implemented to penalize the Turkish road transporters" (T3).

b) "Bulgaria, Romania, and Hungary. Too long waiting times for country entries. Controls and entrance processes take much time to complete" (T8).

Transporters' opinions on what kind of problems they face in the EU countries: 
The participants were asked the question of "What kind of problems does your company face in the EU countries?". Short visa durations for the Turkish drivers (f:7) and an insufficient number of transit permits for the Turkish trucks (f:8) and weakening of competitive power of the Turkish transporters due to the first two reasons (f:6) were defined by the all transporters as main problems faced in the EU countries. Different implementations of CEMT permits ${ }^{11}$ application principles (f:9) is another critical problem for the Turkish road transporters ((T4), (T7), (T8), (T11), (T15), (T17) and (T18). Some of the participants (T1), (T8), (T16) pointed out the different treatments and arbitrary behaviors of the police officers (f:5) as a problem.

Some answer examples about the permits and visas:

a) "Especially insufficient number of transit permits of Hungary, Austria, and Italy is a reason for depletion of them in a short time. This situation creates a serious problem for the Turkish road transporters" (T3).

b) "CEMT permits are a great advantage for the Turkish transporters. However, these permits are distributed according to certain criteria. So, not all companies have this type of permits, and each company has a different number of CEMT permits. On the other hand, the companies that have not CEMT permits are obliged to follow another route, which increases costs. Moreover, transporters are unable to fulfill the services of their customers, who are the Turkish exporters mainly" (T7).

Some answer examples about the competitiveness problems of the Turkish road transporters:

a) "Short Schengen visa durations of our drivers cause the waste of time and the waste of employment that create additional costs, weaken the competitive power and increase the freight costs for the Turkish exporters" (T6).

b) "The transit permit quotas applied to vehicles with Turkish license plates do not apply to vehicles belonging to EU member states. This situation creates an unfair competition environment" (T3).

11 A CEMT permit (CEMT = Conférence Européenne des Ministres des Transports / European Conference of Transport Ministers) allows companies to transport freight across national borders between CEMT countries (besides the OECD this also includes many East and Southeast European countries). The CEMT permit does not authorise domestic traffic or transportation between a CEMT member state and a non-member state. The permits are issued by the competent Ministry of Transport or Commerce. Their use is subject to strict regulations that also encompass the vehicle categories (EURO 1 - 4). There is no legal claim for being granted permits. The permit must be carried on each journey - with or without a load - and completed before departure. The permit is valid for one calendar year. 
c) "Competition is vital for the market and trade in order to provide better service. However, this competition must be fair" (T17).

Transporters' opinions on the importance of the modernization of the EU-Turkey Customs Union:

The participants were asked the question of "How important is the modernization of the EU - Turkey Customs Union?". All participants agreed that it is very important to update the agreement as soon as possible (f:10).

Transporters' opinions on the scope of the modernization of the EU - Turkey Customs Union:

The participants were asked the question of "How the scope of the EU - Turkey Customs Union must be updated for transporters?" All participants answered that non-quota transits (f:11) and free movement of truck drivers (f:12) are the two significant points that must be included in the modernization of the Customs Union.

Some answer examples about the scope of the modernization of the Customs Union:

a) "It is allowed to free movement of goods within the framework of the Customs Union. However, the free movement of Turkish trucks and Turkish drivers that carry these goods is limited" (T8).

b) "The visa necessity for Turkish drivers and quota limitations for Turkish trucks must be abolished. The Customs Union must be updated so that Turkish logistics service providers have the free movement right in the EU countries" (T17).

Transporters' opinions on the possible effects of the modernization of the EUTurkey Customs Union on Turkish road transportation sector:

The participants were asked the question of "What can be the possible effects of the modernization of the Customs Union on Turkish road transport service providers?" All participants made the common emphasis that removing the problems mentioned above, an updated version of the Customs Union will benefit Turkish international road transport service providers (f:13).

Some answer examples about the possible effects of the modernization of the Customs Union on Turkish road transport service providers:

a) "It will be easy for Turkey to do business and to trade with the EU countries. It also will save time and decrease the costs for Turkish road transporters, exporters and importers" (T2). 
b) "It will increase the trade potential of Turkey. The volume of Turkey's foreign trade will increase. The transport services will be more fast and operative" (T14).

c) "It will provide time and economic benefit" (T9).

d) "Turkish road transporters do not operate on equal terms with the EU's road transporters. The modernization of the Customs Union can provide equal operation conditions and fair competition" (T15).

e) "With the modernization of the Customs Union, the extra controls of transit permits, scales and tachographs can be removed that are the wasting time for Turkish transporters" (T6).

\section{Conclusion}

Consequently, the EU - Turkey Customs Union has been in force more than twenty years. Significant progress has been made during this period, both in the EU and Turkey, as well as in the world. While the EU enlarged its borders, the candidacy process was started for Turkey. Moreover, terms and scope of trade between countries changed and entered a new and different stage, covering more than goods - services, public procurement, and investments. Technological developments increased trade while shortening distances in the world. Today the Customs Union of 1996 is far from meeting the necessities that emerged as the results of mentioned changes. From this point of view, it became inevitable to update the conditions of the Customs Union. The decision of the Court of Justice of the EU dated 19.10.2017 about that Turkish trucks transporting goods in the EU member states do not have to pay taxes was a turning point for the Turkish road transportation companies. The reason for the background of the mentioned decision was the punishment of a Turkish truck by the Hungarian tax authorities. Turkish company refused to pay tax because it constitutes a contradiction to the Customs Union. The court has decided to support this attitude. However, because of limited quotas of transit permits, Turkish road transporters pay different amounts of fees in each of the EU member states for every entrance when the quota is exceeded. The fact that the EU is Turkey's first trade partner, it is not difficult to consider the losses of the Turkish side. However, there is not any quota limitation for the foreign road transporters, and they benefit from carrying Turkish goods to the third countries.

In the light of current conditions, this research found that the EU member states' authorities create several obstacles for Turkish road transporters, exactly transit permit quotas, and fees, complexities in professional driver visa procedures, high costs and restrictions on stay lengths. This situation weakens the competitiveness of 
them, violating the principle of free movement of goods, which is the basic principle of the Customs Union. Thus, it is a definite necessity to consider the inclusion of services, exactly road transportation and visa liberalization for drivers within the modernization of the Customs Union, which will provide fair competitiveness between road transportation sectors of Turkey and the EU.

\section{References}

Dedeoglu, B. (2015). Uluslararasi Ilıskilerde Ozel Bir Alan: Bolgesel Butunlesme. Kuramlar, Yaklasimlar, Modeller. Istanbul: Yeniyuzyil Yayinlari.

Gocmen, I. (2016). Ic Pazar. In Avrupa Birligi: Tarihce, Teoriler, Kurunlar ve Politikalar, edited by B.Akcay \& I.Gocmen. Ankara: Seckin, pp.383-405.

Gursel, S. \& Dedeoglu, B. (2010). Turkiye-Avrupa Birligi Sarmalinda Ayricalikli Ortaklik Elestirisi. Istanbul: Hosgoru.

Iktisadi Kalkinma Vakfi (2019). Turkiye-AB Gumruk Birligi, available at: https://www.ikv.org.tr/ikv.asp?ust_id=4\&id=38 (11.10.2019).

Karluk, R. (2005). Avrupa Birligi ve Turkiye. Istanbul: Beta.

T.C. Ticaret Bakanligi (2019). Avrupa Birligi, available at: https://www.ticaret.gov.tr/disiliskiler/avrupa-birligi/yani-basimizdaki-dev-pazar-avrupa-birligi (11.10.2019).

Uluslararasi Nakliyeciler Dernegi (2018). Karayoluyla Uluslararasi Esya Tasimaciligi Sektoronun 2019-2020 Strateji Plani, available at: http://www.und.web.tr/UND2019-2022.pdf (11.10.2019).

Yildirim, A. \& Simsek, H. (2003). Sosyal Bilimlerde Nitel Arastirma Yontemleri. Ankara: Seckin Yayınlari.

Yildirim A. \& Simsek H. (2006). Sosyal Bilimlerde Nitel Arastirma Yontemleri, Ankara: Seckin Yayınlari.

Yilmaz, B. (2013). Gumruk Birligi'nin Teorik Cercevesi. In Yarim Asrin Ardindan TurkiyeAvrupa Birligi Iliskileri, edited by B.Akcay and S.Akgul Akmese. Ankara: Turhan Kitapevi, pp.207-217. 